\title{
Green Accounting Concept Based on University Social Responsibility as A Form of University Environmental Awareness
}

\author{
Muh Akil Rahman ${ }^{a}$, Sumarlina, Sari Fatimah Mus ${ }^{\text {a }}$, Murtiadi Awaluddina ${ }^{\text {, }}$ Rulyanti Susi \\ Wardhanib \\ ${ }^{a}$ Islamic State University Alauddin Makassar, Indonesia \\ ${ }^{b}$ Bangka Belitung University, Indonesia \\ muhakil.rahman@uin-alaudin.ac.id
}

\begin{abstract}
Environmental issues are not a new issue, environmental degradation and social gaps in the environment are a matter of great concern. This study aimed to analyze the form of environmental responsibility and how the application of Green Accounting concept in a university. This qualitative research used phenomenology approach with Interpretative Phenomenological Analysis technique where the research locations were in UIN Alauddin Makassar and Hasanuddin University Makassar. Data source was primary data obtained through interview and also supported by other secondary data. Method of data analysis was constructing research conclusion by abstracting empirical data collected from the field. Findings of this study revealed that the awareness of UIN Alauddin Makassar to the environment is still inadequate and not fulfil the expectations of the campus community that is different from the responsibility of Hasanuddin University Makassar which has been considered quite responsible with the existence of various environmental conservation programs. Green Accounting concept that can be seen from environmental concerns and environmental involvement in these two universities is also very different especially in terms of building management awareness, cost availability and environmental compliance studies. As for the reporting and environmental audit, both UIN Alauddin Makassar and Hasanuddin University Makassar has not been conducted until now.
\end{abstract}

\section{Article Info}

- Received : March 8, 2019

- Revised : May 10, 2019

- Published : June 18, 2019

- No. Pages : $164-178$

- DOI : $10.33019 /$ ijbe.v3i2.156

- JEL : M14, M41, Q56

- Keywords : green accounting, university social responsibility, environmental cost

\section{Introduction}

$50 \%$ of the Earth covered with native forest has vanished, most of it has been destroyed within three decades. This illustrates how environmental issues actually have developed long before the cold war era. But the movement that began to focus on and fight for environmental issues in the international forum could only be said to have started since around the 1970s, more precisely after the Stockholm Conference on The Environment in 1972 followed by the development of 
research related to the issue of Green Accounting in 1980s. The attention to environmental issues developed rapidly both in theory and practice. It can be seen from so many regulations related to environment (Susilo and Astuti 2014).

Indonesia, based on the report of the Indonesian Forum for the Environment (WALHI) noted that the deforestation rate reached 680,000 ha/year, where the highest environmental destroyer actors were companies, followed by the government, and then the next biggest destroyer was the combinations between those, companies and the government. The basics of the policy regarding the environment began since the enactment of the Environmental Law in 1982. In the field of accounting in 1994, the Indonesian Accounting Association (IAI) then set up a standard of environmental accounting disclosure in the Statement of Financial Accounting Standards (PSAK) No. 32 concerning forestry accounting and PSAK No. 33 concerning general mining accounting, in its development the two PSAKs have been withdrawn, and accounting for the environmental impact of company activities can be seen in PSAK No.1 and PSAK No.57. An explanation of the presentation of environmental impacts in PSAK No.1 revision 2009 paragraph 12 is as follows: "Entities can also present, separate from financial statements, reports on the environment and reports of value-added statements, especially for industries where environmental factors play an important role and for industries that consider employees as a group of report users who play an important role. These additional reports are outside the scope of Financial Accounting Standards".

Related to the issue of environmental damage, the Qur'an explained in Surah Ar-Rum Verse 41: The damage on land and at sea can be seen due to the actions of human hands; God wants them to feel a portion of (the result of) their actions so that they could come back (to the right path). Several campuses in Indonesia currently are competing to develop and build sanitation and environmental management systems in campus areas that are based on 3R Concept (Reduce, Reuse, Recycle). This is motivated by several factors including implementing the university function as the role model, the government requirement, an appreciation in the form of the Green Campus predicate from the UI Green Metric Ranking of World Universities (Raharjo et al. 2014). If within the university level, social responsibility is known as the University Social Responsibility (USR) where universities have responsibilities to the university stakeholders, namely employees, lecturers, students, and communities around the campus, USR must also try to meet the expectations of various parties related in an effort to get support and trust from the community. The university's level of concern for the environment is not only can be seen from the cleanliness maintained in campus but also needs to be viewed in terms of attention, involvement, reporting and auditing or re-assessment of the environment. Based on this phenomenon, the objectives of this study are 1) To analyze the forms of environmental responsibility of Islamic State University Alauddin Makassar and Hasanuddin University Makassar; 2) To analyze the concept of Green Accounting based on University Social Responsibility at Islamic State University Alauddin Makassar and Hasanuddin University Makassar.

\section{Theoretical Background}

\section{Legitimacy Theory}

Legitimacy can be regarded as equating perceptions or assumptions that actions taken by an entity are desirable, appropriate or in accordance with the system of socially developed norms, 
values, beliefs and definitions. Legitimacy is considered important for companies because the legitimacy of the community to the company is a strategic factor for the company's future development. Legitimacy theory is based on the notion of social contracts that are implied between social institutions and society (Ahmad and Sulaiman 2004). The theory is needed by institutions to achieve goals to be congruent with the wider community.

\section{Stakeholder Theory}

The concept of corporate social responsibility has been known since the early 1970s, which is known as stakeholder theory that is a collection of policies and practices that relate to stakeholders, values, compliance with legal provisions, community and environmental rewards, and business commitments to contribute to sustainable development. Stakeholder theory starts with the assumption that values explicitly and undeniably are part of business activities. Stakeholder theory says that a company is not an entity that only operates for its own benefits but must benefit its stakeholders as well. Thus, the existence of a company is strongly influenced by support provided by stakeholders to the company (Ghozali and Chariri. 2007).

\section{Institutional Theory}

Institutional theory originated from studies in the field of Sociology. Sunarto 2004) expresses Emile Durkheim's opinion which states that the study of Sociology is the study of institutions. The use of the term institution then develops into economic, political, legal or organizational studies. Institutional theory put emphasis on the social structure. This theory considers how structures, such as schemes, rules, norms and routines, become authoritative forms of social behaviour. So, in this case, the institution not only includes rules, values, and certain habits but also implicate the actions that occur and how the action is repeated (reproduced) (Darono, Nugroho, and Najib 2013).

\section{Green Accounting}

According to Cohen and Robbins (2011), Green Accounting is the activity of collecting, analyzing, and preparing reports related to the environment and financial data in order to reduce the impact and costs of environmental damage. According to the Ministry of the Environment in the Green Accounting Guidelines (2005), Green Accounting includes identifying the costs and benefits of environmental conservation activities, providing information through quantitative measurement, supporting communication in terms of achieving sustainable business development, and maintaining mutually beneficial relationships with the community, and achieving the effectiveness and efficiency of environmental conservation activities. Bell and Lehman (2003) defined Green Accounting as follows: "Green Accounting is one of the contemporary concepts in accounting that support the green movement in the company or organization by recognizing, quantifying, measuring and disclosing the contribution of the environment to the business process."

Based on the Green Accounting definition above, it can be explained that Green Accounting is accounting in which it identifies, measures assesses and discloses costs related to company activities dealing with the environment (Aniela 2012). The aim of Green Accounting according to Astuti (2012) is to increase the amount of relevant information made for those who need or use it. The success of Green Accounting does not only depend on the accuracy in classifying all the costs made by the company, but also the ability and accuracy of the company's accounting data to reduce the environmental impact arising from the company's activities. Other objectives 
of the importance of Green Accounting are companies and other organizations that include the interests of public organizations and public companies that are local in nature.

\section{Environmental Awareness}

Environmental awareness is shown by the appreciation of nature. It is essential that respect for nature is the realization that human beings are part of nature, so be responsible for nature also loves human life. If everyone loves the environment and nature, then all will care to maintain the survival of the environment by never over-exploiting nature so that sustainability nature's life will be maintained (Dewi 2015).

\section{Environmental Management Accounting}

In IFAC 1998 Statement, Management Accounting Concepts, Management Accounting (MA) has evolved through 4 main stages; in the period before the 50s, where the MA was focused on the determination and control of costs. In 1965, it turned into a tool to provide information for management of planning and control. In 1985, the MA became a tool to reduce the usage of resource used in business processes, and since 1995 the MA has been widely used to create value - or as value generation through effective use of resources.

\section{University Social Responsibility}

The university as an entity seems to be made more strategic in using public policies that may become space in the world, to utilize available educational innovations for institutions and influence sustainable and effective change in the community and global society. In the "sustainable Groove" community portal, Richard Goosen suggests that universities are, in fact, the stage for leadership activities and they can choose to become followers in an initiative in the corporation or "seize the opportunity to be leaders and adopt a vital aspect of their competitive advantage"

\section{Previous Studies}

Hidayat (2016), the disclosure of Green Accounting in Indonesia is still voluntary, and there is no strict regulation over this. Thus, there are still many business entities that have not properly disclosed Green Accounting. From the results of several studies showing that in companies with a larger size, there is a tendency for better green accounting disclosure, this is because the larger the size of the company, the higher the demand for information transparency. Where the disclosure of green accounting reporting is actually important information for investors because it can be seen the description of company harmony in managing the environment so as to reduce the risks and possible costs arising from environmental damage. Sari and Hadiprajitno (2013), responsibility for their environment in terms of their probabilities are not accepted and partially accepted. While partially environmental awareness, environmental reporting, environmental audits are not accepted and are accepted by their probabilities.

\section{Research Methods}

\section{Research Approach}

The type of research used in this research is qualitative research based on phenomenological research approach. Phenomenon can be viewed from two angles. First, phenomenon always "points out" or relate to reality outside the mind. Second, the phenomenon from the point of our consciousness, because phenomenology is always in our consciousness. Therefore, in looking at the phenomenon, it should consider seeing "filtering" (ratio), so as to get pure awareness 
(Hardiansyah 2013) wrote that phenomenology is the science of the essence of consciousness and the ideal essence of objects object as a correlation with consciousness. This phenomenology study is aided by Interpretative Phenomenological (IPA) analysis. IPA in Smith and Osborn (2008) aims to reveal in detail how participants interpret their personal and social world.

\section{Type and Source of Data}

The type of data used in this study is subjective data obtained from interviews with informants. The data of this study are derived from primary data obtained by means of in-depth interviews with informants who are considered competent in their fields. The data used were subjects from interviews with informants and documentary data. The informants referred to in this study were: Head of UIN and UNHAS Environmental Unit, UIN and UNHAS Environmental Observer, UIN and UNHAS Financial Report Compiler Staff, UIN and UNHAS Auditor Team, UIN and UNHAS Cleaning Service, UIN and UNHAS Students.

\section{Data Analysis Technique}

The method used to analyze the data in this study is qualitative analysis method. The researcher will build his research conclusions by abstracting empirical data collected from the field and looking for patterns contained in those data.

\section{Results}

\section{Environmental Awareness of Alauddin Makassar State Islamic University and Hasanuddin University Makassar}

In Islamic State University (UIN) Alauddin Makassar, there is no concrete evidence that can be measured as a form of UIN's responsibility for the environment. Various development programs are so urgent to be prioritized and immediately implemented on this campus. The priority of the program is based on problems, potentials and needs in the area of Campus 2 UIN Alauddin Makassar. The physical development of space utilization in the area of Campus 2 UIN Alauddin Makassar, which is felt to be so rapid, tends to be less orderly, inharmonious and incongruent with its environment while the legal instruments for the construction of regional facilities and infrastructure have yet to be firm. Inaccuracies and delays in solving problems in the area will require more labour, time and economic costs and social costs. This was confirmed by the Second Deputy Dean of the Faculty of Medicine and Health Sciences, Dr. A. Susilawaty as environmental observer and compiler of the draft environmental policy at Islamic State University Alauddin Makassar that: "The responsibility of UIN for the environment has not yet been counted, it is still very small to be measured. Even though UIN has a spatial document, it should be followed but UIN ignores it, so what is intended to be built, it would be built as it is."

The same opinion expressed by the Head of the Centre for Environmental and Population Studies of UIN Alauddin Makassar, Nur Syam AS., ST., M.Sc that: "This campus had previously been formulated in spatial planning and it has already been seen that this is an existing building that refers to spatial laws which states that 30 percent of it should function as an ecological, even if it possible, the campus can allocate more than 30 percent will be better. But this was not implemented. But there is already a typical Green Open Space (RTH) concept in 3-dimensional garden design where these gardens reducing air pollution." 
Related to this, some UIN students also expressed their opinion towards the environmental awareness of UIN, as follows: "Of course, improvements need to be made. I hope that UIN organizes its environment so that it looks more beautiful again. Considering I am only as a student and not really know about environmental responsibility at UIN, I personally can give judgement like that." (Nurul Aini Ridwan).

"A little bit disappointed with our campus which empowered civilization, whereas as an Islamic university we have to care about the environment. Lots of garbage, lack of garbage bin or something like that, the physical development did not pay attention to the ecological side of the environment, like trees being cut down converting into building land and parking area. " (Ampe Daryanti).

"The environmental responsibility of UIN from what I have seen so far is still very inadequate. We can see from the large amount of garbage scattered around the UIN. Not only that, but the roads are also not good, for example, the entrance roads and the roads near the Tarbiyah faculty which were flooding frequently. As the students who have been in the UIN for several years feel disappointed with the campus. Even though UIN is an Islamic university that knows very well how Islam teaches us to protect the environment and cleanliness. So, I hope the management of UIN can be further improved." (Haerani Ahmad).

"In my opinion, it is not yet, especially regarding the condition of waste management that is still scattered, the smell of cafeteria waste is still annoying and very disturbing to the resting activities there." (Sudirman).

It can be concluded that UIN Alauddin is still lack of Environmental Awareness. This can be seen from the lack of waste handling in universities and the tendency of UIN to fulfil the need for the development of the Campus 2 area of UIN Alauddin Makassar only in the form of physical development.

Apart from this, UIN Alauddin Makassar has several efforts in terms of environmental management, as stated by Mr. Nur Syam (Chair of the Centre for Environmental and Population Studies at UIN Alauddin Makassar) that: "The form of university responsibility has been seen from some improvements such as renovating the field which has recently been repaired in such a way, then painting the building, then conducting a study on the placement of traffic signs on campus, then facilitating the existence of an environmental and population study centre and those are the part of the campus responsiveness related to the environment and other efforts that are contained in the master plan."

To synergize the physical development program with non-physical programs, UIN Alauddin Makassar has established a development activity plan for Campus 2 area of UIN Alauddin Makassar through the preparation of Master Plan Campus 2 UIN Alauddin Makassar which is a manifestation and effort to control the better utilization of Campus 2 Area of UIN Alauddin Makassar, which is an adequate arrangement in building and environmental management through Local Building Regulations (PBS). Regarding environmental issues, there is value of preserving the environment that already known well. Prompts for humans to preserve nature (not to damage the environment) are found in Al-Qur'an surah Al-A'raf verse 56: "and do not cause any destruction on the surface of the earth, after (Allah) repaired it and prays to Him with fear (will 
not be accepted) and hope (will be granted). Verily the mercy of Allah is very close to those who do good."

The Hasanuddin University program has made the campus a city forest area with the existence of it as Green Open Space (RTH). Based on Law No. 26 of 2007 concerning Spatial Planning, a city is required to have a public green open space. Vegetative land is often called Green Open Space (RTH), which is a form of urban land use that is intended for urban greening (Abril, 2009). Related to this, UNHAS students confirmed that UNHAS itself is an urban forest area, as stated: "As a stakeholder, the UNHAS campus itself is a university that cares and is responsible for the environment, making UNHAS as a city forest is certainly a form of UNHAS's concern for the current environmental conditions." (Daniel Pata Saung).

In line with what was conveyed by Faisal Rahman who said that: "UNHAS's responsibility for the environment has been pretty good but still needs to be improved. Why do I say it's pretty good, because UNHAS is now an urban forest area and when there is a renovation happened in FEB-UH, the trees are not cut down, so it is designed to be environmentally friendly." (Faisal Rahman).

"Environmental awareness in the UNHAS sphere in terms of physical developments in environmental management, UNHAS is categorized as the university that is environmentally responsible, such as the existence of green open spaces and improvements to facilities that support UNHAS as urban forest areas." (Made Junistya).

"When it comes to responsibility and environmental care at UNHAS, it is quite good, by becoming UNHAS as a city forest, of course, this is one proof that UNHAS is a university that aware about the environment." (Nursatri Ausisari).

"So far UNHAS has been paying attention to the environment, such as RTH, which is a form of environmental concern, in fact working with outside parties, because reforestation is a form of environmental care, cleaning up waste, all forms of UNHAS responsibility. Then yesterday there was a tree planting movement on campus which was a bureaucratic instruction for all working units to plant trees in their respective work areas." (Muh. Imadudin Akmal).

From the results of the interview above, it can be explained that Hasanuddin University is a university that is responsible for environmental preservation. One form of concern and responsibilities of Unhas in the environment is making the campus with an area of 2.4 HA as an urban forest area. In addition, the instructions from the bureaucracy related to tree planting in their respective work areas are also an effort of Hasanuddin University in maintaining environmental sustainability. Hasanuddin University in terms of environmental management, especially in terms of cleanliness and waste treatment at the university, is handled by a cleaning service, further explained by Prof. Dadang A. Suriamiharja, M.Eng that: "To manage waste here, the university collaborates with third parties, namely outsourcing parties, such as the cleaning services over there."

With the existence of a cleaning service that is in charge of handling university waste, it is also one form of university involvement in the environment. The Cleaning Service that works in UNHAS itself comes from PT. RIZTECHINDO. Regarding waste handling in universities, 
researchers interviewed one of the cleaning services' supervisors, Mr. Amir, said that: "This waste is processed every day and brought to the landfill in Antang, both wet garbage and others like all kinds of plastic are directed to the landfill. In UNHAS, it is not evenly separated, all immediately taken. Containers and other trash cans, namely sulo, are provided which means that the garbage that has been collected is poured into sulo. We have a garbage collection that is pulled by the container taken with the car and brought here from the container directly to the landfill, so basically, the cadets (cleaning service field section) put in the sulo taken by the car and then poured here."

\section{Green Accounting Concept based on University Social Responsibility in Islamic State University Alauddin Makassar and Hasanuddin University Makassar}

\section{Environmental Awareness}

The university's awareness of the environment is shown by how to understand and respond to environmental problems that occur. The University, which is an educational institution deserves to increase the awareness of its students to have concern for their surrounding environment. FEBI students from Islamic State University Alauddin Makassar responded to environmental problems as follows: "Right now, the issue related to the environment is an issue that attracts a lot of people's attention. Moreover, there has been an increasing number of cases related to pollution and environmental damage. As a place and provider of life, the environment becomes very important for humans. Therefore, the issue related to environmental damage is a very urgent issue to be discussed." (Nurul Aini Ridwan).

"The issue of environmental damage is very worrying nowadays, there are a lot of places experience environmental destruction, there is pollution of the waste, community waste is scattered everywhere. We as the community, considered it as a common thing and that is common, so when we are faced with environmental problems, our response is normal, because this thing is used to being seen. " (Ampe Daryanti).

"The issue of environmental damage is still not prioritized, many still do not realize the importance of preserving the environment, because, from my point of view, there are still many people throwing garbage carelessly, companies that dispose of waste and it is very detrimental to the environment because it can disrupt ecosystems in the environment." (Sudirman).

From the response, it can be concluded that the FEBI UIN Alauddin Makassar students responded to the issue of environmental damage as a matter of concern, this is because pollution and environmental damage are still not prioritized and are only considered normal by the community and companies that dispose of garbage and waste. The concerns of UIN Alauddin Makassar students related to environmental problems are not supported by students' awareness of environmental preservation in their own universities, as stated by the Head of the Centre for Environmental Assessment and Population of UIN Alauddin Makassar, Nur Syam AS, ST., M.Sc. that: "The university's environmental regulations exist, and it becomes an appeal only for the concern and awareness of the campus community, especially among the students, if there are garbage facilities, they are usually damaged, signs are violated, grass-covered sidewalks are used as shortcuts." 
Lack of student awareness of the environment needs to be built by providing education and other forms of awareness building through the Character-Building Training program conducted for three days, some students are not yet aware of it. This also happened because of the lack of environmental education in UIN. Regarding the environmental problems, students of Faculty of Economics and Business, Hasanuddin University understand and respond: "At present, the issue of the environment becomes a problem that needs more attention. The environment is now beginning to experience damage caused by human actions themselves. Along with rapid economic development, of course, there is a negative impact caused by that development. One of them is the most affected is the environment." (Sakinah).

"Environmental damage has actually become a fairly classic problem, but in recent years it has become the government's focal point because the impact that is felt is getting worse so that it has an impact on survival. To overcome this, the government / all stakeholders are more directed to activities to preserve the environment by inviting people to come down directly in preserving their closest environment." (Nursatri Ausisari).

"Environmental damage is an unavoidable thing especially when we see that Indonesia is a developing country, the rapid development of industries, housing, property and so on, is not required that environmental damage will not occur, but we can avoid it, the way to avoid it by following government regulations that have been set. Now what I have seen and what I have learned is that the environmental damage is quite severe, why I say this because of the case with the reclamation of the province in our country, the reduction of forests as the lungs of the world as industrial land for factory, actually this can be prevented in various ways." (Nur Multazam Nurdin).

From the results of the interview above, UNHAS Faculty of Economics and Business students were very aware and concerned about the environmental damage that occurred. Environment is the most important thing to be given attention, environmental problems are unavoidable, but this can be overcome if an entity is able to understand the surrounding environment and there is an awareness of the interdependence of the environment. Hasanuddin University not only builds the awareness of students related to environmental issues, but Hasanuddin University also pays attention to these issues both in theory and practice. Interview with the Head of the Centre for Environmental Research and Development, Hasanuddin University Prof. Dr. Dadang A. Suriamiharja, M. Eng said that: "The university has a role to provide environmental education so in terms of the university's obligations, it must provide learning on how to manage a good environment. All courses concerning any subject are definitely related to their environment especially. In principle, science is divided into two, namely the first knowledge of humans, law, social economics and the science of nature, then the second is the interaction between nature and humans, the interaction of nature and humans, medicine, agriculture, animal farming, fisheries, interactions between nature and all humans pointing to how to shape healthy people, establish sustainable agriculture, how to sustain livestock, because it's all talking about sustainability so that is the scope in terms of filling student conditions."

Explanation of the results of the interview that the form of UNHAS's attention to the environment is to provide learning programs about the environment in each department both majors related to human and nature as well as related subjects between humans and society. 
IJBE (Integrated Journal of Business and Economics)

e-ISSN: 2549-3280/p-ISSN: 2549-5933

\section{Environmental Involvement}

\section{The Existence of an Environmental Unit}

Mid-Year 2017 UIN Alauddin Makassar through the Chancellor's Decree on Environmental Sustainability Policy has formed an environmental unit with the name of the Centre for Environmental and Population Studies in collaboration with the LLD SILE - Canada. Head of the Centre for Environmental and Population Studies, Mr. Nur Syam AS., ST. M.Sc explained the beginning of the unit: "The name of the study centre is the Centre for Environmental and Population Studies which was formed in 2017. The forerunner of the study centre was previously from the Regional and City Study Centres at the Faculty of Science and Technology. Because the names of regional and municipal study centres were too specific and could not involve everyone then it was transformed into a centre for environmental and population studies, so that all crossfaculties can enter or be involved in it."

University of Hasanuddin Makassar has an environmental unit, the Centre for Environmental Research and Development, or commonly abbreviated as PUSLITBANG-LH UNHAS, with the mission of implementing the Tridharma function of Higher Education in the field of environmental management through partnerships with government, private and public institutions, besides that, the unit which is established since 1983 was also given the trust to carry out AMDAL, UKL and UPL studies, and to carry out the Compiling AMDAL course and Appraisal AMDAL and also carried out a number of training in other environmental development fields. Mr. Agus Ranete Lembang who is a staff member at the Research and Development Centre of LH said: "The university has been involved and is responsible for the environment. It can be seen from the formation of the PUSLITBANG-LH in 1983 which used to be called PSL where if there were things that caused environmental damage, for example, or there was pollution, the rector usually told us that there was pollution in this section. not only within the scope of the university but outside the university scope also usually calls our team to deal with this by the way the agency corresponds to the chancellor and the rector informs us. In addition, the establishment of the PUSTLITBANG-LH also provides upgrading of human resources improvement in terms of the environment here."

\section{Availability of Environmental Costs}

UIN Alauddin Makassar in terms of costs related to the environment has been budgeted for 2018, as stated by pak Jufriadi, one of the financial staffs of UIN Alauddin Makassar that: "For environmental costs included in maintenance costs such as the provision of garden maintenance, yard maintenance and cleaning services carried out by third parties. Then we have budgeted for the improvement of the environment, if it is done then it becomes a cost. The budget is the budget for road repairs in 2018, drainage repairs within the campus of UIN Alauddin, and the budget for the chaos of the parking lot to be made just as parking spaces. For the cost of waste, we have not budgeted it yet."

University of Hasanuddin Makassar even the costs included in environmental costs are also listed as maintenance costs, wherein an institution there must indeed be a maintenance fee as stated by one of the staff preparing the financial statements of Hasanuddin University, Mrs. Karmina that: "For the processing of waste and garbage included in the cleaning service, this has been combined with waste management, included in maintenance costs .UNHAS only receives one financing for cleaning services of 13,571,829,000 per year." 
In addition, the UNHAS Green Open Space (RTH), one of the forest and lung areas of the city of Makassar, is an improvement in pedestrian access that is integrated with sewage and rainwater channels and maximizes water absorption is a grant fund obtained by UNHAS, as quoted from the statement of the Mrs. Karmina that: "For RTH in front of UNHAS, it is carried out by the contractor PT. Palindo Inti Nusantara with a contract value of 9.3 billion Rupiah and supervisory consultant PT. Sulappapa Media Utama with a contract value of Rp. 195,000,000 obtained from Grant funds for UNHAS."

The Availability of Program of Management and Reduction of Natural Resources Usage The natural resource program at UIN Alauddin Makassar exists but it is still on a small scale, moreover, there is no reduction in consumption or efficiency. But it does not rule out the possibility that this will continue to occur because UIN Alauddin itself has an action plan in managing environmental sustainability. It was stated by Dr. A. Susilawaty: "Actually the program must be huge, so far environmental programs exist, including third parties, that is an environmental management effort, including tidying up the park, although there are still many things that are lacking, such as the efficiency of energy use on campus that we don't have at all."

Related to the environmental program carried out by Hasanuddin University in reducing consumption of natural resources, according to Prof. Dadang A Suriamiharja. M.Eng that: "In UNHAS there was a fire. The fire was environmental damage. So the fire comes from a load that is too heavy so we reanalyze the calculation between the load and the cable that is electrified."

Furthermore, the Head of PUSLITBANG-LH explained that in addition to the other environmental programs being carried out, it was a program to overcome air pollution, as stated that: "Motor cars emit emulsions which are a factor in environmental damage. The cars emit the carbon dioxide or $\mathrm{CO} 2$ if there are no trees as soon as there is rain in action with $\mathrm{H} 2 \mathrm{O}$ to carbonic acid can make rust. But, the CO2 that comes out of this machine is directly captured by chlorophyll in the leaves. So that oxygen absorbs and from chlorophyll, oxygen products will be produced. UNHAS itself is a contributor to the city's oxygen. UNHAS was originally a forest, we continued to care for trees and also planted teak trees to grow quickly, but not only that, in UNHAS there were many types of trees growing, all of them were given names."

From the interview, it can be concluded that Hasanuddin University Makassar as an urban forest area and city oxygen donors have several programs in an effort to preserve the environment, in addition to providing an understanding of the environment to campus stakeholders, efforts to reduce resource consumption, and rescue air pollution. plant trees as a renewal and continue to care for trees that are still alive before UNHAS stands.

\section{Environmental Safety Studies}

The occupational safety and environmental studies at Alauddin UIN can be seen from interviews with the Head of the Environmental and Population Study Centre that: "The realization does not yet exist but has been contained in a document, for example, prevention if a disaster such as fire or earthquake occurs, but it is only contained in documents because there are no applications such as simulations when a disaster occurs, environmental safety has not been disclosed openly to campus stakeholders." 
Based on the results of the interview above, the UIN Alauddin Makassar has plans to get involved in workplace safety and environmental studies. They understand the theory of safety studies, but there are no applications. Hasanuddin University has applied work safety and environmental studies. As in the interview with Prof. Dadang A. Suriamihardja explained the study of occupational and environmental safety at Hasanuddin University as follows: "So every building that is going to be built has its own contractor. The contractor's head is advised to be friendly to the environment, to hold safety rules for rehabilitated buildings. The workers working there are also safe from accidents. Safety First is a slogan that must be read by every worker who wants to enter the working area, prioritizing safety then there is also keeping a clean environment and usually workers before work, every day they will have the briefing first. That's the rule given by UNHAS to contractors. Because we also don't know that if we don't have a rule, we might be careless, we could be harmed, but Alhamdulillah, all this time, the high-rise building was built and the accident was controlled and given the requirements for that."

Furthermore, janitors or cleaning service both on duty in the field and in the building also applied it. As stated by Mr. Amir as follows: "Before starting the activity, at 7 am, we briefed first, reminding cadets about work safety in using cleaning equipment, especially machinery, and environmental safety. That has become a rule here."

From this, it is clear that the University of Hasanuddin Makassar in terms of environmental involvement especially in safety studies has become a rule, every construction worker and janitor perform a briefing before starting work.

\section{Environmental Reporting}

Islamic State University Alauddin Makassar for environmental reporting has not been specifically contained in financial reports. As stated by Ms. Dr. A. Susilawaty said: "Environmental costs, explicitly exist such as maintenance costs but the cost allocation is not in the Green Accounting concept or environmental cost report."

Similar to what was said by Mr. Nur Syam, AS., ST., M.Si related to environmental reports that: "Specifically, it is not spoken, but in reality, I think it is implemented because there are activities and programs every year and there is a budget, including the provision of environmental maintenance."

This was also confirmed by the staff compiling financial statements of UIN Alauddin Makassar Mr. Jufriadi said that: "Well, there is, there is a budget to do related to the environment, but in detail, the budgets join in maintenance costs, including cleaning services. For cleaning service costs, there are financial statements in the application of SAIBA (Accounting Information System) in the form of accrual accounting. For cleaning service activities all come from outsourcing parties, we only pay the outsourcing party."

The statement can reflect that there are no specific environmental cost reports in the financial statements at Alauddin UIN Makassar, these costs are explicitly still combined with maintenance costs. At the University of Hasanuddin environmental reporting has not been applied to the financial statements or annual reports of the university, as mentioned by Ms. Karmina that: "For environmental maintenance here, it includes maintenance of machinery, buildings, including cleaning service costs for the maintenance of tools, facilities and infrastructures. But if for the 
specifics such as maintenance of the building is not there, there is a detailed fee only for the cleaning service included in the maintenance fee account."

From the results of the interview, it can be seen that Hasanuddin University Makassar did not report in detail the activities and costs in environmental management, the university combined all costs in maintenance costs starting from the maintenance of equipment, buildings, and cleaning and processing of university waste. In terms of financial reporting, University of Hasanuddin Makassar only follows the format provided previously.

\section{Environmental Auditing}

The environmental audit itself has never been carried out at UIN Alauddin Makassar, apart from because there are no financial reports in terms of environmental costs, the audit of UIN Alauddin Makassar also refers to the regulation of the presence of higher education internal audits. As emphasized by Mr. Syarif: "The environmental audit conducted by Internal Audit Unit does not yet exist, our team's internal audit consensus does not mention the environmental audit because if we refer to the regulation on the presence of SPI in higher education, it is more on nonacademic performance and derivatives, other personnel, finance and administration, no one has touch to the environment."

For the supervision of the environment itself as explained by Mr. Nur Syam AS. ST., M.Sc that: "There must be environmental supervision, the supervision is directly through the university administration and general section. Just as in the department that uses a laboratory that produces chemicals and there is a treatment that is provided, before disposing of used laboratory equipment, it is sterilized or neutralized before being disposed of so as not to pollute the environment."

From the interview above it is clear that for the review, supervision and examination of the environment on the campus of Makassar's UIN Alauddin has never been done specifically by the Internal Audit Unit team. Environmental monitoring at UIN Alauddin Makassar and evaluation of the performance of janitors is generally carried out by the university administration and public section. Hasanuddin University Makassar does not have a Green Accounting audit report or a special internal supervisory system to audit the environment at UNHAS, as stated by Dr. Asri Usman, SE., M.Sc., Ak., CA. one of the SPI UNHAS Teams that: "There is no environmental audit report yet because all environmental-related costs are included in the financial statements in general, there are no reports that specify environmental costs specifically. So for the Green Accounting report, it doesn't exist yet."

It is in line with the explanation of Prof. Dadang A. Suriamiharja, M. Eng that: "There is no. Now there is a financial audit, supervision or environmental review reported by security guards and supervisor cleaning service if there is a buildup of garbage or the presence of waste that has not been cleared."

From the explanation above, it can be concluded that Hasanuddin University has never conducted an environmental audit because the costs related to the environment are maintenance costs in general financial statements. However, in the case of direct environmental reviews, security guards and supervisors check the environment and reprimand if there is a buildup of waste due to the negligence of cleaning service. 
IJBE (Integrated Journal of Business and Economics)

e-ISSN: 2549-3280/p-ISSN: 2549-5933

\section{Conclusion and Suggestion}

\section{Conclusion}

The responsibility and awareness of UIN Alauddin towards the environment are still very inadequate and cannot be measured. The responsibility of Hasanuddin University seems to have made the campus a city forest area and the lungs of Makassar city and supported by the existence of UNHAS green open space. UIN Alauddin Makassar students respond to environmental damage issues needed to be considered but not supported by the awareness of students.

Hasanuddin University Makassar students are very aware and concerned about the environmental damage that occurs. Student awareness of the environment can be seen from the planting of 100 trees by students in each faculty and each student must be responsible for 1 tree. There is no MOU between the university and government environmental units because the unit has not been well socialized. The availability of environmental costs starting to be budgeted in 2018 budget includes the cost of repairing drainage, repairing roads and repairing parking lots.

Resources management and reduction have been carried out but still on a small scale and there has been no effort to reduce consumption or energy efficiency. Safety studies have not yet been implemented but with the master plan, showing the effort for being an environmentally conscious university. Since the establishment of the environmental unit at UNHAS, there have been many forms of cooperation is done, both from the city government and the private sector. The availability of environmental costs with the amount of 3 billion is allocated for maintenance costs, together with the cost of preservation repairs derived from grants, management and reduction of natural resources have been applied as well as safety studies that have become a rule in the university environment. There is no specific Green Accounting Report found. UIN now prioritizes the application of the budget to accredit the university. There are no detailed environmental reports yet, but support for the application of green accounting is available if there is instruction from the decision maker. For the internal supervisory unit, the audit of UIN Alauddin Makassar on the environment has not been conducted yet, in general, forms supervision is carried out by the administration and general section of the university and the security guard of Hasanuddin University has not conducted an environmental inspection by the Internal Control Unit but for environmental reviews and inspections the supervisor has cooperated with the university security guard.

\section{Suggestion}

The university needs to encourage more attention to environmentalists at UIN Alauddin Makassar and also engage in any cooperation in order to achieve the goal of "green and clean university". UIN Alauddin Makassar needs to culminate the concern on environment by the concrete actions such as regulating waste processing, and applying the arranged master plan, as well as the curriculum design, competency standards, and teaching and learning processes need to be made with more consideration to environmental aspects. UIN Alauddin Makassar and Hasanuddin University Makassar should allocate a special budget to deal with environmental problems and explore the unit of activities which are environmentally friendly.

UIN Alauddin Makassar and Hasanuddin University Makassar need to have a report on environmental performance. Environmental performance reports that allocate special costs for the environment that are reported continuously and published. UIN Alauddin Makassar and Hasanuddin University Makassar need to conduct environmental related audits, for this reason, 
the university needs to have an Internal Supervisory Unit that is competent in the environmental field to ensure that the university's environmental and special budget allocation programs are effective and efficient. This research was only conducted on two State Universities in South Sulawesi, especially in Makassar City. As a suggestion for future researchers, it is hoped that conducting research on private tertiary institutions which is clearly profits oriented, as well as increasing the number of universities from other cities to compare the quality of the research.

\section{References}

1) Al-Qur'an and Its Translation.

2) Ahmad, N. K., and Sulaiman, M. (2004). "Environmental Disclosures in Malaysian Annual Reports: A A LEGITIMACY THEORY PERSPECTIVE.” International Journal of Commerce and Management. https://doi.org/10.1108/10569210480000173.

3) Aniela, Y. (2012). "Peran Akuntansi Lingkungan Dalam Meningkatkan Kinerja Lingkungan Dan Kinerja Keuangan Perusahaan." Berkala Ilmiah Mahasiswa Akuntansi.

4) Astuti, N. (2012). "Mengenal Green Accounting." Permana.

5) Bell, F., and Lehman, G. (2003). "Recent Trends in Environment Accounting: How Green Are Your Accounts?” Accounting Forum. https://doi.org/10.1111/1467-6303.00010.

6) Cohen, N., and Robbins. (2011). “An A to Z Guide.” Http://Dx.Doi.Org/10.4135/9781412973816. 2011.

7) Darono, A., Nugroho, L. E. and Najib, W. (2013). “Tinjauan Interpretatif Terhadap Aspek-Aspek Institusional Dalam Implementasi Layanan Elektronik : Studi Kasus PT . XYZ.” Jnteti.

8) Dewi, S. R. (2015). "Pemahaman Dan Kepedulian Penerapan Green Accounting : Studi Kasus Ukm Tahu Di Sidoarjo Understanding And Application Of Green Accounting Awareness : A Tofu Sme Case Study In Sidoarjo." Ekonomi \& Bisnis.

9) Ghozali, and Chariri. (2007). Teori Akuntansi. Semarang: UNDIP.

10) Hardiansyah, A. (2013). "Teori Pengetahuan Edmund Husserl." Jurnal Substantia.

11) Hidayat, M. (2016). "Perkembangan Green Accounting Dan Penerapannya Dalam Menjawab Permasalahan Lingkungan Di Indonesia." Artikel Ilmiah Mahasiswa.

12) Ministry of the Environment. (2005). Environmental Accounting Guidelines. Japan. https://www.env.go.jp/en/policy/ssee/eag05.pdf. (diakses : 7 Desember 2017)

13) Raharjo, S., Zulfan, M., Ihsan, T., and Ruslinda, Y. (2014). "Perencanaan Sistem Reduce, Reuse Dan Recycle Pengelolaan Sampah Di Kampus Universitas Andalas Limau Manis Padang." Jurnal Dampak. https://doi.org/10.25077/dampak.11.2.79-87.2014.

14) Sari, M. P., and Hadiprajitno, P. B. (2013). "Pengawasan Implementasi 'Green Accounting' Berbasis University Social Responsibilities (USR) Di Universitas Negeri Semarang.” Jurnal Akuntansi \& Auditing.

15) Smith, J. A., and Osborn, M. (2008). "Interpretative Phenomenological Analysis." In Doing Social Psychology Research. https://doi.org/10.1002/9780470776278.ch10.

16) Sunarto, K. (2004). Pengantar Sosiologi. Jakarta: Lembaga Penerbit Fakultas Ekonomi, Universitas Indonesia.

17) Susilo, J. and Astuti, N. (2014). "Penyusunan Model Green Accounting Untuk Perusahaan Melalui Perhatian, Keterlibatan, Pelaporan Akuntansi Lingkungan Dan Auditnya." Permana. 